\title{
The Effective of Using Cobalt on the Productivity of Summer Squash
}

\author{
Nadia Gad and M.E. Fekry Ali
}

Plant Nutrition Dept., Agricultural and Biological Research Division, National Research Centre, 33 El Buhouth St., 12622 Dokki, Giza, Egypt

Received: 25 Nov. 2019 / Accepted 30 Jan. 2020 / Publication date: 20 Feb. 2020

\begin{abstract}
Two field experiments were carried out to evaluate the effect of cobalt on summer squash growth, quality and yield. Experiments were conducted at Research and Production Station, National Research Centre, El-Nobaria Site, Beheara Governorate, Egypt under drip irrigation system during 2017 and 2018 seasons. Seedlings (at three truly leaves) irrigated once with cobalt levels (0.0, 5.0, $7.5,10.0,12.5$ and $15.0 \mathrm{ppm}$ ). The obtained results are indicate that: All cobalt rates significantly increased squash growth and yield parameters, minerals composition and chemical contents were compared with untreated plants, Cobalt at rate of $10 \mathrm{ppm}$ resulted the superior values for all parameters of squash plants. As cobalt rate increasing in plant media, the promotive effect of cobalt reduced.
\end{abstract}

Keywords: Squash, (Cucurbita pepo L.), cobalt, growth, yield

\section{Introduction}

In Egypt squash (Cucurbita pepo L.) is one of the most important vegetable crops. The "Esandrany) " variety is the main cultivar of squash grown as summer and autumn crop near cities where most of the crop is used for local consumption as well as for export. The total area devoted for this crop was estimated to be $37000 \mathrm{ha}$, and their yield $17798 \mathrm{~kg} / \mathrm{ha}$. (Arab Organization for Agricultural Development, 2016).

Physiological and biochemical processes of plant growth are mainly affected by the nutrition station of the plant.

Cobalt is a beneficial element for higher plants, also an essential element for the synthesis of vitamin $B_{12}$ which is required for human and animals nutrition (Young, 1983). Cobalt does not accumulate in human today with age as the other heavy metals (Smith, 1991).

Cobalt-dense compounds found are necessary for the plant to resist fungal and insect attack. Consumed by animals and humans, these compounds act and anti-oxidant (Griffths and Lunce, 2001).

Cassan et al. (2001) pointed that, both Auxins and Gibberllins enhancement the activation of specific, enzyme which participates RNA and protein synthesis. Nadia Gad (2005) showed that the addition of $7.5 \mathrm{ppm}$ cobalt had significant promotive effect on tomato and cucumber plants dry weight and fruits quality. Cobalt at $7.5 \mathrm{ppm}$ increased the content of $\mathrm{N}, \mathrm{P}$ and $\mathrm{K}$ but further increase reduced it.

Nadia Gad and Abd El-Moez (2011) added that cobalt addition significantly increase the broccoli growth, head yield and its quality compared with untreated plants. Nadia Gad et al. (2017) stated that, under salinity condition, cobalt help cucumber plants to tolerate. Cobalt (from 10 to 20 ppm) significantly increase cucumber growth and yield parameters with control. Holah et al., (2019) show that, all cobalt rates significantly increased tomato plants growth, yield quantity and quality.

\section{Materials and Methods}

Two field experiments were carried out to evaluate the effect of cobalt on summer squash growth, yield, mineral composition and chemical constituents of squash fruits. Experiments were conducted at Research and production station, National Research Centre, EL-Nobaria Site, Beheara Governorate, Delta Egypt under drip irrigation system during 2017 and 2018 seasons.

Corresponding Author: Nadia Gad, Plant Nutrition Dept., Agricultural and Biological Research Division, National Research Centre, 33 El Buhouth St., 12622 Dokki, Giza, Egypt 


\section{Soil analysis:}

Physical and chemical properties of Nubaria soil were determined and particle size distributions along with soil moisture were determined as described by Blackmore (1972). Soil pH, EC, cattions and anions, organic matter, $\mathrm{CaCO}_{3}$, total nitrogen and available $\mathrm{P}, \mathrm{K}, \mathrm{Fe}, \mathrm{Mn}, \mathrm{Zn}, \mathrm{Cu}$ were run according to Black et al., (1982 ). Determination of soluble, available and total cobalt was determined according to method described by Cottenie et al., (1982). Physical and chemical properties of Nubaria soil are shown in Table (1)

Table 1: Physical and chemical analysis of the experimental soils in Nobaris Station

\begin{tabular}{|c|c|c|c|c|c|c|c|c|c|c|c|}
\hline \multirow{3}{*}{ Physical } & \multicolumn{3}{|c|}{$\begin{array}{c}\text { Particle size distribution } \\
(\%)\end{array}$} & \multicolumn{2}{|c|}{$\begin{array}{l}\text { Soil texture } \\
\text { class }\end{array}$} & $\begin{array}{c}\text { Water } \\
\text { saturation }\end{array}$ & \multicolumn{2}{|c|}{$\begin{array}{c}\text { Field } \\
\text { capacity }\end{array}$} & \multirow{2}{*}{$\begin{array}{c}\text { Welting } \\
\text { point }\end{array}$} & \multicolumn{2}{|c|}{$\begin{array}{c}\text { Available } \\
\text { water }\end{array}$} \\
\hline & Sand & Silt & Clay & \multirow{2}{*}{\multicolumn{2}{|c|}{ Sandy loam }} & \multicolumn{5}{|c|}{$\%$} & \\
\hline & 82.6 & 14.6 & 2.8 & & & 32.0 & \multicolumn{2}{|r|}{14.4} & 3.9 & \multicolumn{2}{|c|}{10.5} \\
\hline \multirow{3}{*}{ Chemical } & \multirow{2}{*}{$\mathbf{p H}^{\mathbf{a}}$} & \multirow{2}{*}{\multicolumn{2}{|c|}{$\mathbf{E C}^{\mathbf{b}}$}} & \multicolumn{4}{|c|}{ Soluble cations (meq/l) } & \multicolumn{4}{|c|}{ Soluble anions (meq/L) } \\
\hline & & & & $\mathrm{Ca}^{++}$ & $\mathbf{M g}^{++}$ & $\mathbf{K}^{+}$ & $\mathrm{Na}^{+}$ & $\mathrm{HCO}_{3}^{-}$ & $\mathrm{CO}_{3}$ & $\mathrm{Cl}^{-}$ & $\mathrm{SO}_{4}=$ \\
\hline & 8.0 & & 1.0 & 9.0 & 1.4 & 0.268 & 3.26 & - & 1.18 & 0.60 & 12.15 \\
\hline \multirow[t]{2}{*}{ Total } & \multirow{2}{*}{\multicolumn{2}{|c|}{$\begin{array}{l}\text { Available } \\
\text { (mg/100g) }\end{array}$}} & \multirow{2}{*}{\multicolumn{4}{|c|}{$\begin{array}{c}\text { Available micronutrients } \\
(\mathrm{ppm})\end{array}$}} & \multirow{2}{*}{$\mathrm{CaCO}_{3}$} & OMc & \multicolumn{3}{|c|}{ Cobalt (ppm) } \\
\hline & & & & & & & & $\mathrm{OMI}^{2}$ & Soluble & Available & Total \\
\hline N & $\mathbf{P}$ & $\mathbf{K}$ & $\mathbf{F e}$ & Mn & $\mathbf{Z n}$ & $\mathbf{C u}$ & $\%$ & 0 & 0.39 & 1.78 & 9.68 \\
\hline 15.2 & 13.0 & 21.2 & 10.7 & 4.47 & 3.62 & 5.22 & 3.17 & 0.19 & 0.39 & 1.78 & 9.68 \\
\hline
\end{tabular}

a Soil $\mathrm{pH}$ was measured in $1: 2.5$ soil-water suspension.

b EC was measured as dSm-1in soil paste.

c organic matter.

\section{Experimental works:}

Two field experiments. Each experiment contains 18 plot. Each plot area $15 \mathrm{~m}^{2}$ (5 X $\left.3 \mathrm{~m}\right)$ containing 3 rows. Each row planted with 10 plants. Seeds of squash (Cucurtita pepo L.), cultivar Eskandrany were sown on September $20^{\text {th }}$ and $22^{\text {th }} 2017$ and 2018 seasons. Seedlings (at three truly leaves) irrigated once with cobalt concentrations: $0.0,5.0,7.5,10.0,12.5$ and $15.0 \mathrm{ppm}$ at the cobalt sulphate form. All plants received natural agriculture practices whenever needed.

\section{Measurement of plant vegetative growth:}

After 30 days from sowing, plant height, number of leaves per plant, fresh and dry weights of both shoots and roots were recorded according to FAO (1980).

\section{Measurement of flowering characteristics:}

Three plants from each treatment were labeled for recorded the following characters:

* Average of days from sowing until the appearance of first female flower.

* Average number of male flower/ plant.

* Average number of female flower/ plant.

* Average sex ratio $=\frac{\text { No. of male flower/ plant. }}{\text { No. of female, flower/ plant. }} \quad$ according to Gabal et al. (1984).

\section{Measurement of fruits yield:}

Squash fruits number/plant, fruits length, fruits diameter as well as fruits weight/plant were recorded according to Gabal et al., (1984).

Early yield per Fadden:

Were calculated as the sum of the yield the first four pickings.

\section{Total yield per Fadden:}

Were calculated as the sum of total all pickings. 


\section{Statistical analysis:}

The obtained data were statistically analyzed of variance procedure outlined by (SAS 1996) computer program and means were compared by LSD method according to Sndecor and Cochran (1980).

\section{Result and Discussion}

\section{Vegetative growth}

Data on Table (2) outline the response of squash growth parameters to different cobalt levels. Data show that, all cobalt concentrations has a significant promotive effect on squash growth parameters such as plant height, number of leaves per plant, fresh and dry weights of both shoots and roots compared with control. Cobalt at $10 \mathrm{ppm}$ resulted the greatest values. As cobalt rates were ranged above $10 \mathrm{ppm}$, the promotive effect reduced. These results are in harmony with those obtained by Nadia Gad and Nagwa Hassan (2013) who found that all cobalt levels significantly increased sweet pepper growth and yield parameters compared with control. Cobalt at $5 \mathrm{ppm}$ gave the highest values.

Table 2: Effect of cobalt on vegetative growth of squash plants (Mean of two seasons).

\begin{tabular}{ccccccc}
\hline $\begin{array}{c}\text { Cobalt } \\
\text { treatments } \\
\text { (ppm) }\end{array}$ & $\begin{array}{c}\text { Plant } \\
\text { height } \\
\text { (cm) }\end{array}$ & $\begin{array}{c}\text { Number of } \\
\text { Leaves } \\
\text { Per plant }\end{array}$ & \multicolumn{2}{c}{$\begin{array}{c}\text { Fresh weight } \\
\text { Per Plant (g) } \\
\text { Shoot }\end{array}$} & Root & \multicolumn{2}{c}{$\begin{array}{c}\text { Dry weight } \\
\text { Per Plant (g) } \\
\text { Shoot }\end{array}$} & Root \\
\hline Control & 31.40 & 14.81 & 44.61 & 10.12 & 14.52 & 2.54 \\
$\mathbf{5 . 0}$ & 35.54 & 16.55 & 46.33 & 10.58 & 14.81 & 2.68 \\
$\mathbf{7 . 5}$ & 37.91 & 18.78 & 48.05 & 12.03 & 15.69 & 3.01 \\
$\mathbf{1 0 . 0}$ & 40.76 & 21.14 & 50.60 & 12.86 & 16.88 & 3.46 \\
$\mathbf{1 2 . 5}$ & 40.19 & 20.36 & 48.91 & 12.25 & 16.57 & 3.12 \\
$\mathbf{1 5 . 0}$ & 18.86 & 19,23 & 46.75 & 11.68 & 15.82 & 2.89 \\
LSD 5\% & $\mathbf{2 . 3 2}$ & $\mathbf{1 . 6 5}$ & $\mathbf{2 . 5 1}$ & $\mathbf{0 . 4 1}$ & $\mathbf{1 . 1 2}$ & $\mathbf{0 . 3 2}$ \\
\hline
\end{tabular}

\section{Flower characteristics}

Data on Table (3) show cobalt has a significant promotive effect on the acceleration onset of female flowers on squash plants in two seasons. As cobalt concentration increase in plant media, the number of days from sowing decrease. Among the various, cobalt at $15 \mathrm{ppm}$ showed the lowest number of days from sowing until the appearance the first female flower.

Table 3: Effect of cobalt on flower characters of squash plants (Mean of two seasons).

\begin{tabular}{ccccc}
\hline $\begin{array}{c}\text { Cobalt treatments } \\
\text { (ppm) }\end{array}$ & $\begin{array}{c}\text { Number } \\
\text { of days for flower }\end{array}$ & $\begin{array}{c}\text { Female } \\
\text { flowers }\end{array}$ & $\begin{array}{c}\text { Male } \\
\text { flowers }\end{array}$ & $\begin{array}{c}\text { Sex } \\
\text { ratio }\end{array}$ \\
\hline $\begin{array}{c}\text { Control } \\
\mathbf{5 . 0}\end{array}$ & 40.25 & 26.06 & 53.36 & 2.048 \\
$\mathbf{7 . 5}$ & 39.50 & 29.54 & 51.71 & 1.751 \\
$\mathbf{1 0 . 0}$ & 37.23 & 31.28 & 50.03 & 1.599 \\
$\mathbf{1 2 . 5}$ & 35.08 & 33.77 & 48.11 & 1.425 \\
$\mathbf{1 5 . 0}$ & 34.91 & 31.18 & 47.92 & 1.569 \\
LSD 5\% & 34.79 & 29.86 & 46.69 & 1.564 \\
\hline
\end{tabular}

Cobalt at $10 \mathrm{ppm}$ was the third concentration for early flowing while control plants resulted the highest values for number of days in two seasons.

Data in table (3) also indicate that, the control plants gave the highest number of male flowers and lowest number of female flowers per plant. Concerning sex ratio resulted the significant reduction with cobalt level in plant media increased.

\section{Yield characteristics}

Data presented in Table (4) clearly indicate that cobalt significantly increased squash yield parameters compared with control. Cobalt at $10 \mathrm{ppm}$ the greatest values of yield parameters such as fruits number per plant, fruits weight per plant, fruits length fruits diameter as well as early and total yield in two seasons. Cobalt at $10 \mathrm{ppm}$ significantly increased early yield about 1.68 ton per feddan 
while total squash yield gave 2.96 ton per feddan. These results are agree with those obtained by Nadia Gad (2005) who found that cobalt significantly promoted all tomatoes yield parameters compared with control.

Table 4: Effect of cobalt on squash yield (Mean of two seasons).

\begin{tabular}{ccccccc}
\hline $\begin{array}{c}\text { Cobalt } \\
\text { treatments } \\
(\mathbf{p p m})\end{array}$ & $\begin{array}{c}\text { Fruits } \\
\text { number/ } \\
\text { plant(g) }\end{array}$ & $\begin{array}{c}\text { Fruits } \\
\text { weight/plant } \\
\mathbf{( g )}\end{array}$ & $\begin{array}{c}\text { Fruit } \\
\text { length } \\
(\mathbf{c m})\end{array}$ & $\begin{array}{c}\text { Fruit } \\
\text { diameter } \\
(\mathbf{c m})\end{array}$ & $\begin{array}{c}\text { Early yield } \\
\text { (Ton/fed.) }\end{array}$ & $\begin{array}{c}\text { Total yield } \\
\text { (Ton/fed.) }\end{array}$ \\
\hline Control & 4.750 & 386 & 11.37 & 2.673 & 1.780 & 4.868 \\
$\mathbf{5 . 0}$ & 4.980 & 471 & 14,80 & 4.022 & 2.166 & 5.934 \\
$\mathbf{7 . 5}$ & 5.619 & 566 & 15.18 & 4.332 & 2.376 & 6.904 \\
$\mathbf{1 0 . 0}$ & 6.260 & 649 & 15.72 & 4.550 & 2.631 & 7.823 \\
$\mathbf{1 2 . 5}$ & 5.781 & 579 & 15.08 & 4.532 & 2.455 & 7.142 \\
$\mathbf{1 5 . 0}$ & 5.652 & 560 & 14.92 & 4.398 & 2.127 & 6.607 \\
LSD 5\% & $\mathbf{0 . 6 3 2}$ & $\mathbf{1 7}$ & $\mathbf{0 . 5 2}$ & $\mathbf{0 . 3 1}$ & $\mathbf{0 . 2 5 1}$ & $\mathbf{1 . 0 6 4}$ \\
\hline
\end{tabular}

\section{Nutritional statues}

Data in Table (5) show that macro-nutrients ( $\mathrm{N}$, plant $\mathrm{K}$ ) in squash fruits significantly increased with all cobalt treatment compared with control in two seasons. Cobalt at $10 \mathrm{ppm}$ resulted the highest values. As cobalt rate in plant media increasing above $10 \mathrm{ppm}$, the prometive effect reduced. These results are good agreement with those obtained by Boureto et al. (2001) who stated that cobalt at 2.5 ppm in solution culture significantly increased the contents of N, P and $\mathrm{K}$ in tomato plants. Confirm these results Holah et al. (2019) who pointed that cobalt at $7.5 \mathrm{ppm}$ has a positive effect on N, P and $\mathrm{K}$ contents in tomato fruits.

Table 5: Effect of cobalt on nutrient status of squash fruits (Mean of two seasons)

\begin{tabular}{ccccccccc}
\hline $\begin{array}{c}\text { Cobalt } \\
\text { treatments } \\
(\mathbf{p p m})\end{array}$ & $\mathbf{N}$ & $\mathbf{N}$ & $\mathbf{~ K}$ & $\mathbf{M n}$ & $\mathbf{Z n}$ & $\mathbf{C u}$ & $\mathbf{F e}$ & $\begin{array}{c}\text { Cobalt } \\
(\mathbf{p p m})\end{array}$ \\
\hline Control & 0.783 & 0.375 & 0,488 & 20,3 & 16.2 & 22.1 & 151 & 0.98 \\
$\mathbf{5 . 0}$ & 0.811 & 0.396 & 0.522 & 22.5 & 18.7 & 24.3 & 149 & 1.86 \\
$\mathbf{7 . 5}$ & 0.867 & 0.421 & 0.556 & 26.0 & 21.0 & 26.0 & 136 & 3.55 \\
$\mathbf{1 0 . 0}$ & 0.926 & 0.450 & 0.578 & 28.7 & 23.6 & 28.7 & 129 & 5.08 \\
$\mathbf{1 2 . 5}$ & 0.917 & 0.439 & 0.570 & 28.0 & 21.9 & 28.0 & 118 & 6.91 \\
$\mathbf{1 5 . 0}$ & 0.906 & 0.422 & 0.559 & 27.1 & 20.7 & 26.9 & 115 & 8.22 \\
LSD 5\% & $\mathbf{0 . 2 8}$ & $\mathbf{0 . 2 5}$ & $\mathbf{0 . 3 2}$ & $\mathbf{0 . 5}$ & $\mathbf{0 . 9}$ & $\mathbf{0 . 7}$ & $\mathbf{3 . 0}$ & $\mathbf{0 . 8 6}$ \\
\hline
\end{tabular}

Data in Table (5) also indicate that all the used levels of cobalt gave the significant beneficial effect on the contents of micronutrients $(\mathrm{Mn}, \mathrm{Zn}$ and $\mathrm{Cu}$ ) of squash fruits compared with untreated plants. These results agrees with those obtained with James (2005) who found that cobalt significantly increased $\mathrm{Mn}, \mathrm{Zn}$ and $\mathrm{Cu}$ content of tomato fruits.

Also Table (5) clearly indicate that the addition of cobalt in plant media resulted in a reduction in Fe content in tomatoes. The reduction rate of $\mathrm{Fe}$ was more or less proportion with the concentration of added cobalt. This indicates, again, the competition between $\mathrm{Fe}$ and $\mathrm{Co}$ in absorption. This may be explained on the basis of results reported by Blaylock (1995) who showed certain antagonistic relationships between the two elements (iron and cobalt). While the content of cobalt in squash fruits significantly increased with the increasing cobalt rate in plant media. These results are agrees with those obtained by Nadia Gad and Nagwa Hassan (2013) who stated that as increasing cobalt level in plant, cobalt sweet pepper. Young (1983) reported that the daily cobalt.

Requirement for human nutrition could reach $8 \mathrm{ppm}$ depending on cobalt levels in the local supply of drinking water without health hazard. Levels of $8.22 \mathrm{ppm}$ in the highest cobalt treatment (15 ppm) is below the dangerous level, since the daily consumption of tomato fruits does not exceed a few grams. 


\section{Chemical constituents}

Data concerning effect of cobalt on chemical contents of squash fruits are given in Table (6). The results reveal that, all cobalt rates has a significant favourable effect in all chemical constituents compared with control. These results are agree with those obtained by Nadia Gad (2012) who reported that cobalt is hence all chemical content in eggplant fruits.

Table 6: Effect of cobalt on chemical constituents of squash fruits (Mean of two seasons).

\begin{tabular}{ccccc}
\hline $\begin{array}{c}\text { Cobalt } \\
\text { treatments } \\
(\mathbf{p p m})\end{array}$ & $\begin{array}{c}\text { Total soluble } \\
\text { solids }\end{array}$ & Total proteins & $\begin{array}{c}\text { Total soluble } \\
\text { sugars }\end{array}$ & Vitamin "A" \\
\cline { 2 - 5 } & & $\mathbf{\%}$ & & $\begin{array}{c}\boldsymbol{\mu} / \mathbf{1 0 0 g} \\
\text { Fresh tissue }\end{array}$ \\
\hline Control & 3.16 & 4.89 & 1.33 & 13.44 \\
$\mathbf{5 . 0}$ & 3.45 & 5.07 & 1.70 & 13.92 \\
$\mathbf{7 . 5}$ & 4.22 & 5.42 & 2.09 & 14.39 \\
$\mathbf{1 0 . 0}$ & 5.69 & 5.79 & 2.45 & 14.88 \\
$\mathbf{1 2 . 5}$ & 5.62 & 5.73 & 2.45 & 14.81 \\
$\mathbf{1 5 . 0}$ & 5.42 & 5.66 & 2.39 & 14.76 \\
LSD 5\% & $\mathbf{0 . 6}$ & $\mathbf{0 . 6 5}$ & $\mathbf{0 . 3 7}$ & $\mathbf{0 . 4 6}$ \\
\hline
\end{tabular}

\section{Conclusion}

Cobalt promising element in the newly reclaimed soils in Egypt. It's help plants tolerate the harmful weathering in this soils. Also it has a promotive effect of squash growth, yield quantity and its quality. Therefore, considerable attention should be taken concerning applying this element (cobalt) as a fertilizer.

\section{References}

A.O.A.C., 1995. Method of analysis. Association of Official Agriculture Chemists. $16^{\text {th }}$ Ed., Washington, D.C.USA.

Arab Organization for Agricultural Development, 2016. STATISTICAL YEAR BOOK, EGYPT, 2018.

Black, C.A., D.D. Evans, L.E. Ensminger, G.L. White and F.E. Clarck, 1982. "Methods of Soil Analysis", Part 2. Agron. Inc. Madispn Wise.

Blackmore, A.D., Jolly and R.H. Walser, 1972. Methods of Chemical Analisis of Soils. Newzealand. Soil Dureau. P A2.1, Dep.No. 10.

Blaylock, A.D., T.D. Davis, V.D. Jolley and R.H Walse, 1993. Influence of cobalt on photosynthesis, chlorophyll and nutrient content in regreening chlorotic tomatoes and soybeans. J. of plant Nutrition. 8:813-828.

Boureto, A. E., and Kagawa, J. N., 2001. Effect of cobalt on sugerbeet growth and mineral content. Revistra Brasileira-Sementes. 18: 63.

Cassan, F., R.C.G. Bottin, and P. Piccoli, 2001. Azospirillum Spp metabolize (17, 17-H-2) Gibberelin, Auxin in vivo in dry rice mutant seedlings. Plant and Cell Physiology, 42; 763-771.

Cottenie, A., M. Verloo, L. Kiekens, G. Velgh and R. Camerlynck, 1982. Chemical analysis of plant and soil. Chemical Analysis of Plants and Soils. PP 44-45. State Univ. Ghent Belgium.

FAO , 1980. Soil and plant testing as a basis of fertilizer recommendation. Soil Bull., 3812.

Gabal, M.R., I.M. Abd-Allah, F.M. Hass and S. Hassannen, 1984. Evaluation of some American tomato cultivars grown for early summer production in Egypt, Annals of Agriculture Science Moshtohor., 22: 487-500.

Griffths, H.R., and J. Lunec, 2001. Ascorbic acid in the $21^{\text {th }}$ Century-more than a simple antioxidant Environ. Toxicol. Pharmacol., 10:173-82.

Holah, Sh. Sh, S.T. Abou-Zeid, Nadia Gad, and M.M. Abbas, 2019. Response of Tomato (Lycopersicum esculentum) to Cobalt Supplement. Plant Archives. 19(1): 817-822.

James, D. B., 2005. Interrelation between minerals plant tissues. J. Plant Nutr., 11:1236.

Nadia Gad, 2005. Effect of cobalt on tomato growth, yield and fruit quality. Egypt. J. Appl. Sci., 20: 260. 
Nadia Gad , 2012. Effect of cobalt on eggplant (Solanum melongena L.) yield quantity and quality. Current Science International 2(1): 13-17.

Nadia Gad and M.R. AbdEl-Moez, 2011. Broccoli growth, yield quantity and quality as affected by cobalt nutrition. Agriculture and Biological J. of North America 2(2): 226-231.

Nadia Gad, and Nagwa Hassan , 2013. Response of growth and yield of sweet pepper (Capsicum annuum L.) to cobalt nutrition. World Applied Sciences Journal 2(5): 760-765.

Nadia Gad, M. R. Abdel-Moez, Doaa M. Abo- Basha and Nagwa M.K. Hassan, 2017. Mitigation the effect of salinity as a result of climate change by using cobalt on tomato production in newly reclaimed lands Current Science International ISSN: 2077-4435. 06 (04): 857-866.

SAS., 1996. Statistical analysis system, SAS users guide: statistics. SAS Institute Inc., Edition, Cary, NC.

Smith, R.M., 1991. Trace elements in human and animal nutrition. Micronutrients News and information. 11(4):9.

Snedecor, G.W. and W.G. Cochran, 1980. Statistical Analysis Methods. 6th Ed. Iowa State Univ. Press. Ames., Iowa, USA.

Young, R.S., 1983. Recent advances on cobalt in human nutrition. Micronutrients News and information. 3(3): 2-5. 